\title{
PERCEIVED CORPORATE REPUTATION AND PRIDE AS DRIVERS OF FRONTLINE EMPLOYEES' REPUTATION IMPACT AWARENESS: MEDIATING ROLE OF JOB SATISFACTION
}

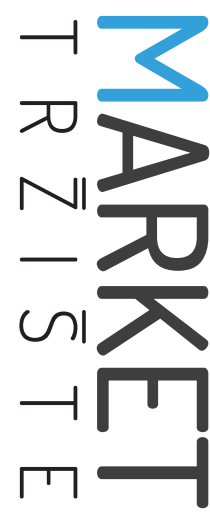

\section{PERCIPIRANA KORPORATIVNA REPUTACIJA I PONOS KAO POKRETAČI SVJESNOSTI KONTAKTNOG OSOBLJA O UTJECAJU REPUTACIJE: MEDIJATORSKA ULOGA ZADOVOLJSTVA S POSLOM}

Market-Tržište

Vol. 31, No. 2, 2019, pp. 171-185

UDK 331.101.32:316.64/.65:658:005.336.6

DOl http://dx.doi.org/10.22598/mt/2019.31.2.171

Original scientific paper

\begin{abstract}
Vesna Babić-Hodovića , Maja Arslanagić-Kalajdžićb
a University of Sarajevo, School of Economics and Business, Trg oslobođenja - Alija Izetbegović 1, 71000 Sarajevo, BOSNIA AND HERZEGOVINA, e-mail: vesna.babic-hodovic@efsa.unsa.ba

b University of Sarajevo, School of Economics and Business, Trg oslobođenja - Alija Izetbegović 1, 71000 Sarajevo, BOSNIA AND HERZEGOVINA, e-mail: maja.arslanagic@efsa.unsa.ba
\end{abstract}

\begin{abstract}
Purpose - Service employees play a crucial role in creating and sustaining the reputation of service firms. Their attitudes and commitment to the firm are reflected in customers' perceptions of quality and loyalty, which ultimately improve corporate performance. The aim of this study is to better understand what contributes to raising frontline employees' awareness of their role in building and sustaining the corporate reputation of service firms.
\end{abstract}

Design/methodology/approach - We adapt Helm's (2011) conceptual framework based on a work-related social identity theory and test the adapted model through an empirical study on 544 service firms' frontline employees.

Findings - Our findings show that job satisfaction of frontline employees is a significant determinant of their reputation impact awareness, as well as a mediator of

\section{Sažetak}

Svrha - Zaposlenici uslužnih poduzeća imaju ključnu ulogu u stvaranju i održavanju reputacije poduzeća. Stavovi zaposlenih i njihova posvećenost poduzeću odražavaju se u percepcijama korisnika o kvaliteti usluge i lojalnosti, što u konačnici unapređuje performanse poduzeća. Svrha rada jest bolje razumjeti što doprinosi podizanju svijesti kontaktnoga osoblja uslužnih poduzeća o njihovoj ulozi u izgradnji i održavanju korporativne reputacije.

Metodološki pristup - Prilagođen je konceptualni okvir koji je razvila Helm (2011), a koji je temeljen na teoriji društvenog identiteta vezanoga uz posao. Prilagođeni je model empirijski testiran na uzorku 544 zaposlenika kontaktne osobe iz uslužnih poduzeća.

Rezultati i implikacije - Rezultati istraživanja pokazuju da je zadovoljstvo poslom kontaktnog osoblja značajna odrednica njihove svjesnosti o utjecaju reputacije, kao i 
the effects that pride and perceived corporate reputation have on corporate reputation impact awareness.

Limitations - Possible existence of other dimensions of perceived corporate reputation, when it comes to internal stakeholders - the employees, present a limitation of this study and should certainly be considered in future research.

Originality/value - We compare and contrast our findings with previous studies and shed more light on internal marketing possibilities targeted towards frontline employees.

Keywords - corporate reputation, frontline employees, employee pride, job satisfaction medijator učinaka koje ponos i percipirana korporativna reputacija imaju na svjesnost o utjecaju korporativne reputacije.

Ograničenja - Ograničenja istraživanja vezana su uz moguće postojanje drugih dimenzija percipirane korporativne reputacije kada su u pitanju interni dionici - zaposlenici, što je potrebno razmotriti u budućim istraživanjima.

Doprinos - Nalazi su uspoređeni s onima iz prethodnih istraživanja i dodatno se rasvjetljavaju mogućnosti internoga marketinga usmjerene prema kontaktnom osoblju.

Ključne riječi - korporativna reputacija, kontaktno osoblje, ponos zaposlenika, zadovoljstvo poslom 


\section{INTRODUCTION}

Employees in service firms are often perceived as the service itself, the brand, or even the organization in customer's eyes and this is particularly true of frontline employees (FLEs). Service employees present one of the key factors in building a firm's positive image and reputation (Elsbach \& Glynn, 1996; Furman, 2010). As the performers on the "front stage" (visible part of the firm), FLEs take an active role not only in delivering services but also in expanding business and sharing positive feelings and trustworthiness with customers. Thus, they can serve as a vital source of differentiation and competitive advantage for the firm (Berry, 1981; Gounaris, 2008; Paswan, Pelton \& True, 2005). Still, even if the literature acknowledges the importance and different position of FLEs (Delcourt, Gremler, van Riel \& van Birgelen, 2013; Hennig-Thurau, 2004; Henning-Thurau, Groth, Paul \& Gremler, 2006; Johnson, 1996) compared to other employees in service firms, studies focusing solely on them are scarce (e.g. Dagger, Danaher, Sweeney \& McColl-Kennedy, 2013; Kumar, Dass \& Topaloglu, 2014; Yoo \& Arnold, 2016).

A broad range of services is generated through the interaction between service employees and customers. Consequently, long-term relationships between customers and a firm greatly depend on the employees (Bowen \& Lawler, 1992), and in particular on FLEs (Schaarschmidt, 2016). FLEs have a direct impact on customers and, hence, the opportunity to convince and advise them during the purchasing phase; therefore, the effect and results of their efforts can be measured in real time. Because of their active position in communication with external markets, they are often seen not only as a communication channel in the service process (Gounaris, 2008; Paswan et al., 2005), but as corporate ambassadors as well (Löhndof \& Diamantopoulos, 2014; Melton \& Hartline, 2010; Seltzer, Gardner, Bichard \& Callinson, 2012). Furthermore, due to their direct contact with customers they are an extremely valuable instrument for collecting data from customers, generating feedback, and measuring direct results of service interaction. FLEs are also in a position to promote, support, or disrupt a service firm's strategic initiatives (Cadwallader, Jarvis, Bitner \& Ostrom, 2010; Harris \& Ogbonna, 2010; McKnight \& Hawkrigg, 2005; Nguyen, Groth, Walsh \& Henning-Thurau, 2014; Porter \& Smith, 2005; Walsh, Yang, Dose \& Hille, 2015), all of which is considered of great importance for the service firm performance. Therefore, their self-perception, as well as awareness of the roles and tasks they provide in the service process, is highly important as the prerequisite for customer satisfaction and loyalty (Allen \& Grisaffe, 2001; Tharenou, Shaks \& Moore, 2007).

This study adapts a general model developed to assess the drivers of employees' awareness of their influence on corporate reputation (Helm, 2011). Although corporate reputation has many facets (Vlašić \& Langer, 2012), this study focuses on employees' perceptions. Work-based social identity theory, with the "central assumption that the collective attributes of the groups, one belongs to are decisive for one's self-definition" (Helm, 2011, p. 658) is foundational for this study. In the context of social identity theory, employees exhibit two forms of identification with the firm's reputation: (1) perception of the corporate reputation of the firm, and (2) reputation impact awareness (Brown, 1997; Cornelissen, Haslam \& Balmer, 2007; Dutton, Dukerich \& Harquail, 1994; Madrigal, 2001). They are even more important for the FLEs as the key players in the service process delivery. When assessing what is relevant for FLEs in the reputational context, the perception of the firm being a "good employer" to reflect FLEs' perception of the firm's corporate reputation (Walsh \& Beatty, 2007) is used.

It is very important for the firm's success that FLEs are able to identify themselves with customers (Gremler \& Gwinner, 2008; Hennig-Thurau \& Thurau, 2003; Korschun, Bhattacharya \& Swain, 2014). FLEs have another relevant role, and that is to convey and instill the message to customers which is consistent with the firm's overall reputation and perception. The latter is possible only if they are closely identified with

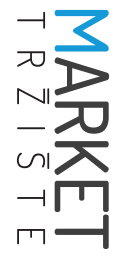


the firm and if they strongly believe in its culture and values (Bartels, Pruyn, de Jong \& Joustra, 2007; Fuller et al., 2006; Gok, Peker \& Hacioglu, 2015; Shamma \& Hassan, 2009). There are many ways through which firms can strategically instill their message to their employees, in particular through their internal marketing efforts; such communication is able to alter beliefs, behaviors, and performance of all employees and of FLEs in particular (Baker, Rapp, Meyer \& Mullins, 2014). However, since the role of FLEs is of crucial importance, their reputation impact awareness might also be relevant in the process of building corporate reputation. In that context, reputation impact awareness can be defined as the degree to which FLEs are aware of their role in internal reputation building which "encompasses all activities or behaviors employees exhibit in order to contribute to the formation of corporate reputation" (Helm, 2011, p. 658).

In line with the presented background, the following research questions have been developed: (1) How is FLEs' perception of corporate reputation and pride related to their job satisfaction? (2) Does job satisfaction determine FLEs' corporate reputation impact awareness? and (3) Does FLEs' job satisfaction act as a mediator for the effects of perceived reputation and pride on FLE's corporate reputation impact awareness? Answering these questions should improve the understanding of the most effective and efficient ways of increasing FLEs' corporate reputation impact awareness, helping in the improvement of internal marketing practices, as well as in FLEs' commitment to their firm's success.

This study contributes to the research on corporate reputation in services by focusing on FLEs and by assessing the mechanisms that drive their reputation impact awareness. The extent to which job satisfaction facilitates the effects of perceived reputation and pride on the awareness by testing for mediating effect is assessed. Finally, the results of this study can contribute to service firms' management in the process of identifying tools for improving internal marketing actions and service firms' performance.
The rest of the paper is structured as follows: A brief literature overview and arguments for the hypotheses are provided first. They are followed by a presentation of the methodology of the study and of its empirical results. Finally, a discussion of the theoretical and managerial implications of the study, as well as its limitations and further research directions, are presented.

\section{CONCEPTUAL FRAMEWORK}

Prior research in services has already demonstrated that FLEs are in charge of the key relationship in the service firm - the one that connects it to their customers (Grönroos, 1984). Specifically, they are responsible for providing high functional quality (quality of service process) and technical quality (quality of service outcome), as dimensions of total service quality. Corporate reputation can be considered a mirror of the corporate history (Nguyen et al., 2014) that sends quality signals to customers (Arslanagic-Kalajdzic \& Zabkar, 2017); it is essentially the result of the confirmed promises given to customers, which means a consequence of FLEs' performance and results.

On the other hand, FLEs are more effective, productive, and committed if they are satisfied (Heskett et al., 1994). Previous studies further show that FLEs' pride and perception of reputation have an important role in their satisfaction (Katzenbach, 2003; Helm, 2011). Tajfel and Turner's (1979) social identity theory embeds these processes by suggesting that "after being categorized in terms of a group membership and having defined themselves in terms of that social categorization, individuals seek to achieve or maintain positive self-esteem by positively differentiating their ingroup from a comparison outgroup on some valued dimension" (Cornelissen et al., 2007, p. 5). The perspective taken in our conceptual model is that perceived corporate reputation, pride, and job satisfaction are antecedents of reputation impact awareness, 
that is, that they help in shaping the degree to which FLEs recognize their role in internal reputation building of their firm. Such causal inference is in line with social identity theory, as well as with previous studies and findings in this field (e.g. Helm, 2011). That is, we believe that FLEs' perceptions of the opinion of others about their firm, as well as their own feelings and attitudes can (de)motivate their internal reputation building appreciation. Against this background, a conceptual framework (Figure 1) that encompasses the perception of reputation and pride as drivers of FLEs' job satisfaction, and job satisfaction as a driver of FLEs' reputation influence awareness and as a mediator as well, is tested. of stakeholders. Helm (2011, p. 657) defines corporate reputation as "... a global, temporally stable, evaluative judgment about the employing firm that is shared by the firm's multiple stakeholders." According to Gotsi and Wilson (2001, p. 29), "...this evaluation is based on the stakeholder's direct experiences with the company, any other form of communication and symbolism that provides information about the firm's actions and/or a comparison with the actions of other leading rivals." It is postulated that being perceived as a "good employer" by FLEs is one of the most important internal reflections of a firm's corporate reputation, and this notion is used in the development of the perceived corporate reputation concept. Moreover, FLEs

FIGURE 1: Conceptual framework of the research

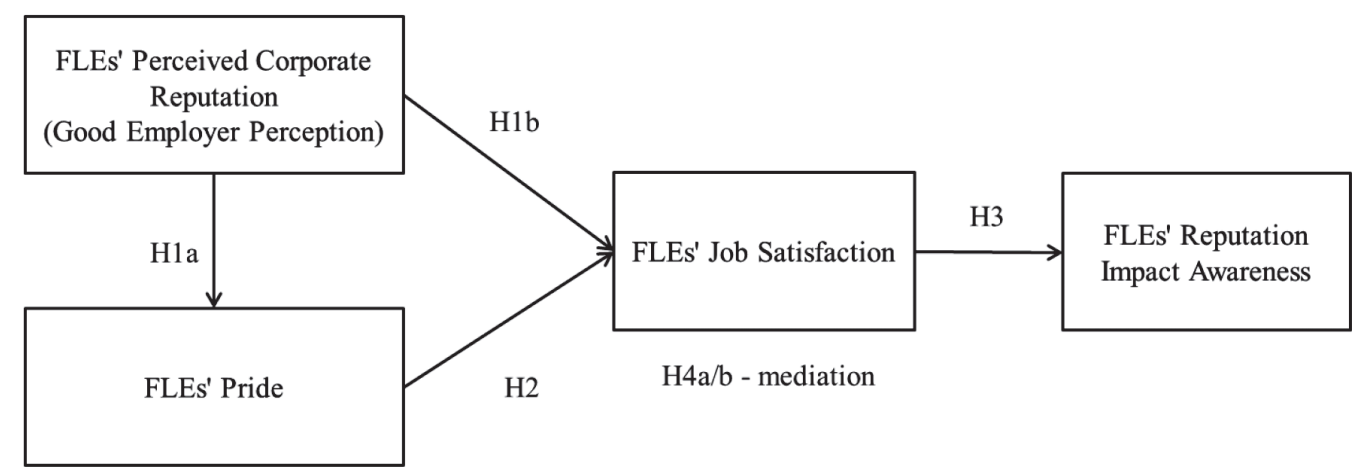

Fombrun (1996) postulates that a good corporate reputation attracts and helps retain customers; in addition, it builds employee loyalty, primarily through increasing their readiness and commitment to implement customer-oriented strategy and building a service-oriented corporate culture. According to the service profit chain proposition (Heskett et al., 1994), perceptions of service employees, and consequentially their attitudes and behaviors, have a crucial influence on the service firm's success and profitability. Following this approach, Chun (2005) stated that employees, as well as managers, are more satisfied and feel safer when an organization has a good reputation in the eyes of a range perception of the "good employer" reputation is under the impact of perceptions formed by other stakeholders. Essentially, stakeholders (i.e. customers, owners, general public) form their perceptions of reputation partly based on how successful the firm is in satisfying their needs and requests, which is ultimately a result of FLEs' actions.

A positive or negative reputation of a firm has the ability to directly influence employees' intention to remain in (or leave) the organization. A good corporate reputation can also positively influence job satisfaction and employees' identification with the organization (Riordan, Gatew- 
wod \& Bill, 1997). Job satisfaction can be defined as "the positive and pleasant affective state, which an individual hold about his or her job" (Locke, 1976, p. 1304). Employee job satisfaction is shaped by the reward system, compensation, and motivation, as well as the process of internal marketing, human resource management, and process control (Quinn \& Magine, 1973). Despite a lot of studies of employee satisfaction and their role in the service provision process, FLEs specifically have not been the focus of previous research. FLEs often serve as ambassadors of their firms and, in the case of high-contact services, they are even equalized with the service firm itself. Therefore, if corporate reputation is high, FLEs will have increased motivation for their work and in turn high job satisfaction. Paradoxically, even when FLEs are not fully satisfied with their work, if they know their firm is perceived as highly reputable and as a great employer by other stakeholders, this will serve as a compensatory factor for satisfaction. Hence, it is hypothesized:

H1a: FLEs' perception of the corporate reputation of the firm they work for (perception of "good employ$e^{\prime \prime}$ ) is positively related to their job satisfaction.

Cropanzano, Byrne, Bobocel and Rupp (2001) state that employees' perception of the organization and its reputation is strongly related to the ways in which the organization treats members of other interest groups outside the organization. In recent times, the organization's participation in different socially responsible activities, initiated by certain causes in local community, strengthens the employees' attitudes towards the organization. Even though several firms have already attributed a large degree of their sustained success to the high levels of employee pride (Katzenbach \& Santamaria, 1999), the construct of "pride" is still a predominantly neglected factor in corporate studies (Lea \& Webley, 1997).

According to previous studies, pride can be conceptualized as a positive emotion or as an attitude. As an affect (Elfenbein, Beaupré,
Lévesque \& Hess, 2007; Katzenbach, 2003) pride can be described as a discrete and intense, albeit short-lived, mental experience (Fisher \& Ashkanasy, 2000). As an attitude which is the result of learnable and also long-lasting experiences (Fairfield, Wagner \& Victory, 2004), pride indicates a long-term opinion which determines behavior. In this study, and in line with the social identity theory, attitudinal pride can be characterized as a form of collective pride resulting from the employees' need for identification with a specific group such as the organization they work for (Lea \& Webley, 1997). For the FLEs this issue is even more important than for other staff. On the one hand, standing in the first lines on the battlefield, they must feel they belong to the company. On the other hand, their attitudes and perception regarding the roles which they have are not studied enough.

The initial trigger that is responsible for experiencing pride is a cognitive comparison between one's actual achievements and one's previous expectations of how the task should be fulfilled correctly. Experienced success, as a specific stimulating event, induces pride and leads to a positive sense of self-worth as well (Eccles \& Wigfield, 2002). Employee pride has been proven to be a factor which increases employees' commitment to a firm and provide customer-oriented services (Gouthier \& Walter, 2006). This is particularly true of FLEs in service firms because, as the perception of corporate reputation of the firm increases, FLEs strengthen their sense of belonging to the firm which is manifested in greater pride. Furthermore, FLEs who are proud of the firm they work for will experience more satisfaction working for that firm than the FLEs who are not. Based on the arguments outlined above, it can be stated that the higher the perception of the firm they work for as being a "good employer", the higher the employee pride in working for that firm as well as their job satisfaction:

H1b: FLEs' perception of the corporate reputation of the firm they work for (perception of "good employer") is positively related to their pride. 
H2: FLE pride is positively related to their job satisfaction.

In its essence, employee job satisfaction has the following main characteristics: (1) it is an individual's response to job experiences; (2) it interpreted as a difference between real job experience and employee expectations about the activities they are supposed to complete; and (3) job satisfaction is usually evaluated according to the results of other employees working at similar positions inside or outside an organization (Salancik \& Pfeffer, 1977). An employee having a position with good reputation and working for a firm with the image of a "good employer" would be proud of the job and may have a higher level of job satisfaction (Chongho, Myungsook \& Yonghwi, 2012).

As an active part of service providing process, employees, currently categorized as internal customers (Berry, 1981), expect an organization to respect their wishes and requests similarly as the external customers who they served. Therefore, by satisfying the needs of employees, and in particular FLEs, the organization improves its capabilities for delivering high quality of services and increasing customers' satisfaction (Gounaris, Vassilikopoulou \& Chatzipanagiotou, 2010). Better quality of the services leads to a sustainable competitive advantage of the firm (Javadein, Rayej, Estiri \& Ghorbani, 2011) and improves market position.

FLEs importance in the context of the service providing process and service quality improvement on one hand and the influence of the FLEs job satisfaction on the customers' satisfaction and loyalty on the other, increase importance of different factors which impact the FLEs importance in corporate reputation creating and sustaining. Using internal marketing strategies (Muriuki, Maru \& Kosgei, 2016; Papasolomou, 2006) service firms can create higher level of FLEs satisfaction and based on that prerequisites for providing high quality services and creating customer satisfaction. Alongside with that, satisfied FLEs will be strongly motivated for the improvement of firms' corporate reputation, by following the adopted service marketing strategy and fulfilling the promises given to the customers in pre-purchase phase. As the favorable corporate reputation is an important managerial goal (Chun, 2005; Ettenson \& Knowles, 2008), FLEs' commitment to it is of great importance in the process of corporate reputation building.

Employee expectations and requests have been changing and developing over time; having high knowledge and professional skills which are necessary in modern markets, they require more for themselves - higher salaries, non-financial rewards, and possibilities for carrier development. Those who experience higher job satisfaction might become more aware of the importance of their roles and positions in the service offerings as well as in the firm's corporate reputation building. Therefore, it is hypothesized:

H3: FLE job satisfaction is positively related to their reputation impact awareness.

FLEs, as representatives of service firms, are the "face" of the firm and are sometimes even equated with the service offer of the firm. For that reason, their job satisfaction will have an even stronger influence on reputation impact awareness than it is true of other employees. Unlike in studies that focus on all employees (i.e. Helm, 2011) where the results show that job satisfaction does not influence employees' reputation impact awareness, for FLEs job satisfaction channels the effects of perceptions and pride on awareness. In other words, even if the identification with the firm occurs, FLEs' awareness on their role for corporate reputation will not occur without job satisfaction. Therefore, it is hypothesized that job satisfaction is part of a mechanism through which the effect of perceived reputation and employee pride is transferred on the awareness among employees of their role regarding the firm's reputation:

H4: Frontline employee job satisfaction mediates the effect of (a) perceived corporate reputation and (b) pride, on their reputation impact awareness.

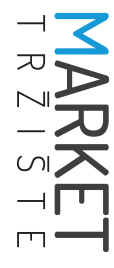




\section{METHODOLOGY}

A quantitative survey was conducted in order to empirically test the hypotheses developed in the conceptual framework. Existing measurement scales were used for the selected constructs: the corporate reputation - "good employer" dimension (Walsh \& Beatty, 2007), pride (Cable \& Turban, 2003), job satisfaction and the employees' awareness of their impact on corporate reputation (Helm, 2011). The following FLE characteristics were controlled for: gender, age, education level, and years of experience.

The survey was carried out in a European country in 2015. A research agency was engaged to collect the responses from a representative sample of FLEs working in professional services in the country. It covered the following industries: law/legal services, accounting and auditing, advertising, consulting, and IT services. Professional services were selected due to their high-contact characteristics that underlie the importance of FLEs.
A total of 544 valid questionnaires were collected and analyzed. Female FLEs made up $64 \%$ of the sample. Most of the respondents (36\%) were in the 26-35 age group, followed by FLEs aged 36-45 (35\%). In terms of education, $46 \%$ of the FLEs had a university degree, followed by those with a high school diploma (45 \%). FLEs' work experience ranged from 1 year to 40 years (full seniority in the country), with the mean of 8 years of service for the firm; most FLEs, however, had been with their current firm for 3 years, indicating a relatively quick rotation in the industry.

\section{RESULTS}

Reliability and validity of the selected measurement instrument were first assessed by conducting a confirmatory factor analysis (CFA) in LISREL 8.71. Consequently, a structural model was estimated in order to test the hypothesized relationships, following a two-step approach (Anderson \& Gerbing, 1988) and using the maximum likelihood (ML) estimation method (Bagozzi \& Yi, 2012). CFA results are presented in Table 1.

\section{TABLE 1: Confirmatory factor analysis}

\begin{tabular}{|c|c|c|c|c|}
\hline Construct & Items & Loading & AVE & CR \\
\hline \multirow{3}{*}{$\begin{array}{l}\text { FLEs' perceived } \\
\text { corporate reputation } \\
\text { (good employer } \\
\text { perception) }\end{array}$} & My company is a good company to work for. & 0.862 & \multirow{3}{*}{0.745} & \multirow{3}{*}{0.898} \\
\hline & My company treats its people well. & 0.869 & & \\
\hline & $\begin{array}{l}\text { My company has management who pays attention to the } \\
\text { needs of its employees. }\end{array}$ & 0.858 & & \\
\hline \multirow{4}{*}{ FLE pride } & I am proud to be part of my company. & 0.815 & \multirow{3}{*}{0.747} & \multirow{3}{*}{0.899} \\
\hline & I am proud when others associate me with my company. & 0.886 & & \\
\hline & I am proud to tell others that I work for my company. & 0.891 & & \\
\hline & Are you satisfied with your: & & & \\
\hline \multirow{4}{*}{ FLE job satisfaction } & ...current salary (compared to industry standards)? & 0.774 & \multirow{4}{*}{0.633} & \multirow{4}{*}{0.873} \\
\hline & ...work tasks and daily responsibilities? & 0.716 & & \\
\hline & ...opportunities for advancement within your company? & 0.832 & & \\
\hline & ...top management on the corporate level? & 0.854 & & \\
\hline \multirow{3}{*}{$\begin{array}{l}\text { FLEs' reputation } \\
\text { impact awareness }\end{array}$} & $\begin{array}{l}\text { What I personally do is important for the reputation of my } \\
\text { company. }\end{array}$ & 0.724 & \multirow{3}{*}{0.633} & \multirow{3}{*}{0.837} \\
\hline & I personally feel like an ambassador of my company. & 0.768 & & \\
\hline & I personally feel responsible for my company's reputation. & 0.886 & & \\
\hline \multicolumn{5}{|c|}{$\begin{array}{l}\text { Fit indices: } d f=59 ; \text { Chi-Square }=203.03(p=0.0) ; \text { Chi-Square \& df = 3.44; RMSEA =0.06; NNFI =0.98; } C F I= \\
0.99 ; S R M R=0.04\end{array}$} \\
\hline \multicolumn{5}{|c|}{ Notes: AVE = Average variance extracted, $C R=$ Composite reliability } \\
\hline
\end{tabular}


It could be seen that, in the final measurement model, all the constructs demonstrated good psychometric properties, consistent reliability, and validity, with the average variance extracted (AVE) higher than the $50 \%$ threshold and composite reliability higher than the 0.70 threshold (in this case, composite reliability for all the constructs was higher than 0.80).

Convergent validity was confirmed as all t-values for the indicator loadings were statistically significant (Anderson \& Gerbing, 1988; Bagozzi \& Phillips, 1982). Data were also tested for common method bias using a marker variable test (Lindell \& Whitney, 2001; Podsakoff, MacKenzie, Lee \& Podsakoff,
2003). The item of reported years of service was used as a marker variable; correlations between this item and selected items from the constructs in the model were all found to be not significant and were lower than 0.2. The discriminant validity was tested, with results shown in Table 2.

Hypotheses testing proceeded in line with the established reliability and validity of the measurement model. One structural model with all focal relationships was estimated and it exhibited excellent fit properties $\left(\mathrm{df}=99 ; \mathrm{X}^{2}=275.08\right.$; $X^{2} \& d f=2.78 ;$ RMSEA $=0.05 ; \mathrm{NNFI}=0.98 ; \mathrm{CFI}=$ $0.98 ; \mathrm{SRMR}=0.04)$. The results of the analysis are presented in Table 3.

\section{TABLE 2: Discriminant validity}

\begin{tabular}{|c|c|c|c|c|c|}
\hline \# & Construct & 1 & 2 & 3 & 4 \\
\hline 1 & $\begin{array}{l}\text { FLEs' perceived corporate reputation } \\
\text { (good employer perception) }\end{array}$ & 0.87 & & & \\
\hline 2 & FLE pride & 0.52 & 0.87 & & \\
\hline 3 & FLE job satisfaction & 0.54 & 0.48 & 0.79 & \\
\hline 4 & FLEs' reputation impact awareness & 0.30 & 0.35 & 0.27 & 0.79 \\
\hline
\end{tabular}

Note: Correlations are shown below the diagonal; Squared-roots of the AVEs in bold on the diagonal

\section{TABLE 3: Hypotheses testing}

\begin{tabular}{|c|c|c|}
\hline Path & $\beta$ & $\mathbf{R}^{2}$ \\
\hline H1a: FLEs' perceived corporate reputation $\rightarrow$ FLE pride & $0.76^{* * *}$ & 0.57 \\
\hline H1b: FLEs' perceived corporate reputation $\rightarrow$ FLE job satisfaction & $0.56^{* * *}$ & 0.69 \\
\hline H2: FLE pride $\rightarrow$ FLE job satisfaction & $0.31^{* * *}$ & \\
\hline Gender $\rightarrow$ FLE job satisfaction & $0.06^{* * *}$ & \\
\hline Age $\rightarrow$ FLE job satisfaction & $-0.08^{* *}$ & \\
\hline Education $\rightarrow$ FLE job satisfaction & $-0.03^{\mathrm{NS}}$ & \\
\hline Years of experience $\rightarrow$ FLE job satisfaction & $0.02^{\mathrm{NS}}$ & \\
\hline FLE pride $\rightarrow$ FLEs' reputation impact awareness & $0.26^{* * *}$ & 0.23 \\
\hline $\begin{array}{l}\text { FLEs' perceived corporate reputation } \rightarrow \text { FLEs' reputation impact } \\
\text { awareness }\end{array}$ & $0.11^{\mathrm{NS}}$ & \\
\hline H3: FLE job satisfaction $\rightarrow$ FLEs' reputation impact awareness & $0.15^{* *}$ & \\
\hline Gender $\rightarrow$ FLEs' reputation impact awareness & $0.01^{\mathrm{NS}}$ & \\
\hline Age $\rightarrow$ FLEs' reputation impact awareness & $0.01^{\mathrm{NS}}$ & \\
\hline Education $\rightarrow$ FLEs' reputation impact awareness & $0.05^{\mathrm{NS}}$ & \\
\hline Years of experience $\rightarrow$ FLEs'reputation impact awareness & $0.12^{* *}$ & \\
\hline \multicolumn{3}{|c|}{ Fit indices: $\mathrm{df}=99 ; \mathrm{X}^{2}=275.08 ; \mathrm{X}^{2} \& \mathrm{df}=2.78 ; \mathrm{RMSEA}=0.05 ; \mathrm{NNFI}=0.98 ; \mathrm{CFI}=0.98 ; \mathrm{SRMR}=0.04$} \\
\hline \multicolumn{3}{|l|}{ Note: ${ }^{* * *}-p<0.001 i^{* *}-p<0.05$} \\
\hline
\end{tabular}




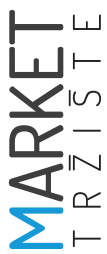

It is evident that perceived corporate reputation positively and significantly influences FLE pride ( $\beta=0.76, p<0.001)$ as well as FLE job satisfaction $(\beta=0.56, p<0.001)$, which is in line with H1a and $\mathrm{H1b}$. Furthermore, FLE pride is positively and significantly correlated to their job satisfaction ( $\beta$ $=0.31, p<0.001$ ), which confirms H2. FLE pride and perceived corporate reputation explain the high percentage of variance of job satisfaction $\left(r^{2}=69 \%\right)$. When it comes to the awareness of the employees of their importance for the firm's corporate reputation, it is significantly influenced by job satisfaction ( $\beta=0.15, p<0.05$ ), thus confirming $\mathrm{H} 3$. Interestingly, the amount of explained variance of FLEs' reputation impact awareness is only $26 \%$, which suggests that there are other unobserved factors which might explain it.

In terms of mediation, FLE job satisfaction fully mediates the effect of the perceived corporate reputation on FLEs' reputation impact awareness since the direct effect is not significant, while the indirect effect of perceived corporate reputation is positive and significant $(\beta=0.32, p<0.05)$. This confirms $\mathrm{H} 4 \mathrm{a}$ and shows that, for FLEs, job satisfaction has a complete mediating role for the effect of perceived reputation on reputation impact awareness. When it comes to the second mediating path, partial mediation effect is established. Specifically, pride has a positive and direct relationship with FLEs' awareness of their impact on corporate reputation $(\beta=0.26, p<0.001)$, and the indirect effect is established as well $(\beta=0.05$, $p<0.05)$. To conduct an additional test of the indirect effects, we utilized recommendations from Preacher and Hayes (2008) by running a mediation model (Model 4) in PROCESS tool V3.1 in SPSS. Mediation was assessed using 5,000 bootstrap samples and $95 \%$ confidence integrals. The indirect effect of corporate reputation on reputation impact awareness was found to be positive and significant $(\beta=0.15$, $[\mathrm{LLCl}=0.07, \mathrm{ULCl}=0.24])$, as was the indirect effect of pride $(\beta=0.11$, [ LLCl $=0.03, \mathrm{ULCl}=0.18]$ ).

The model was controlled for four control variables: gender, age, years of service, and edu- cational level. Both dependent variables in the model were controlled for (job satisfaction and AICR), and established that FLE gender and age significantly influence job satisfaction (gender, $\beta$ $=0.06, p<0.001$, age, $\beta=-0.08, p<0.05$ ), while job experience is only related to FLEs' awareness of their impact on corporate reputation (years of experience, $\beta=0.12, p<0.05)$. When it comes to job satisfaction, female employees and younger employees tend to exhibit higher job satisfaction. In terms of reputation influence awareness, the longer an FLE works for the organization, the higher his or her awareness of their impact on the firm's reputation.

\section{DISCUSSION AND CONCLUSIONS}

The present research study contributes to the existing knowledge on the role of employee perceptions of the creation of job satisfaction and their awareness of their own role for building the firm's corporate reputation. FLEs' perceptions of reputation are conceptualized through the "good employer" reputational dimension. In this study, additional evidence that accompanies recent studies is provided to show the importance of corporate reputation in the eyes of the service firm's internal stakeholders - the employees (Helm, 2011; Schaarschmidt, 2016), specifically those who in their work have direct interaction with customers, i.e. FLEs. What needs to be stressed is that FLEs are often perceived as the service itself; for sure, they are the most responsible for the successful service process and fulfillment of the firm's promises. So, this study has important managerial implications with respect to their internal marketing efforts.

When it comes to the theoretical contribution of this study, job satisfaction of FLEs is strongly determined by their corporate reputation perceptions and their pride. Evidence provided shows that investment in corporate reputation building and in positioning the firm as a "good employer" in the minds of its stakeholders yields 
fruit in terms of the employees job satisfaction, which is also in line with a recent discussion by Arikan, Kantur, Maden and Telci (2016). The strength of the effect of pride is almost two times weaker than the influence of perceived reputation. Significant positive effect shows that managers should build a culture and shape corporate actions in a way that evokes pride on the part of their employees. Perceived reputation and pride complement other firm's efforts invested in increasing and sustaining FLE job satisfaction.

Furthermore, the Helm (2011) approach was adapted and an already established link between job satisfaction and employee awareness of their impact on corporate reputation was tested. Contrary to the results of the original study, where the direct relationship between job satisfaction and employee awareness of their impact on corporate reputation was found to be non-significant, this study found a significant relationship, as well as a significant mediating role of job satisfaction for the effects of perceived corporate reputation and pride of FLEs. Job satisfaction hence serves as a channel through which both perceived reputation and pride contribute to the FLEs awareness. As is well established in theory, FLEs are the key factor for service delivery and for shaping clients' experiences. Consequently, their role in terms of the creation of corporate reputation is perceived by external stakeholders to be immense.

Evidence that job satisfaction acts as the determinant of FLEs' awareness is an important signal for managers aiming to improve their firms' corporate reputation. That effect was shown to operate differently with FLEs than with other employees in previous studies. This finding implies that service firms' managers should use a segmented approach to their internal marketing activities and develop separate actions for FLEs if they want to achieve a full effect of their role for corporate reputation development. While with other employees of the firm awareness is achieved merely by identification (i.e. through perceived reputation and pride), for FLEs job satisfaction is crucial for the awareness. Another finding that is interesting for managers concerns the significant effect of the years of experience on the reputation impact awareness. This implies that more experienced employees also have a higher awareness of their role in this context; they have already been in situations when their skills and knowledge helped in conflict resolution and when, in turn, that type of reaction would be rewarded by the management, thus leading to an increase in job satisfaction over an extended period. These results signal to managers that first-line employees in services firms could be utilized as a major strength in the process of building and sustaining the firm's corporate reputation.

When it comes to the limitations of this study, possible existence of other dimensions of perceived corporate reputation for internal stakeholders - the employees, should be considered. This avenue should be explored in further research as there are no multidimensional corporate reputation measurement instruments for stakeholders other than consumers. This is a cross-sectional study that cannot capture how FLEs' perspective is to evolve over time and whether their current perception of corporate reputation and their current level of pride are related to future reputation impact awareness; hence, a longitudinal study of these concepts can be considered in further research to capture the concepts in focus over time. Furthermore, the reputation-based antecedents and outcomes of job satisfaction should be modelled together with classical, human resource-based management in terms of job satisfaction determinants and outcomes, in order to capture the bigger picture and expand the understanding of this topic. The FLE and customer engagement, as well as their co-creation efforts, could also be included in order to further develop the insights into how the FLEs' awareness of their impact on corporate reputation is built. 


\section{References}

1. Allen, N., \& Grisaffe, D. (2001). Employee commitment to the organization and customer reactions: Mapping the linkages. Human Resource Management Review, 11, 209-236.

2. Anderson, J. C., \& Gerbing, D. W. (1988). Structural equation modeling in practice: A review and recommended two-step approach. Psychological Bulletin, 103(3), 411-423.

3. Arikan, E., Kantur, D., Maden, C., \& Telci, E. E. (2016). Investigating the mediating role of corporate reputation on the relationship between corporate social responsibility and multiple stakeholder outcomes. Quality \& Quantity, 50(1), 129-149.

4. Arslanagic-Kalajdzic, M., \& Zabkar, V. (2017). Hold me responsible: The role of corporate social responsibility and corporate reputation for client-perceived value. Corporate Communications: An International Journal, 22(2), 209-219.

5. Bagozzi, R. P., \& Yi, Y. (2012). Specification, evaluation, and interpretation of structural equation models. Journal of the Academy of Marketing Science, 40(1), 8-34.

6. Bagozzi, R. P., \& Phillips, L. W. (1982). Representing and testing organizational theories: a holistic construal. Administrative Science Quarterly, 27(3), 459-489.

7. Baker, T. L., Rapp, A., Meyer, T., \& Mullins, R. (2014). The role of brand communications on front line service employee beliefs, behaviors, and performance. Journal of the Academy of Marketing Science, 42(6), 642-657.

8. Bartels, J., Pruyn, A., de Jong, M., \& Joustra, I. (2007). Multiple organizational identification levels and the impact of perceived external prestige and communication climate. Journal of Organizational Behavior, 28, 173-190.

9. Berry, L. (1981). The employee as customer. Journal of Retail Banking, 3, 25-28.

10. Bowen, D. E., \& Lawler, I. (1992). The empowerment of service workers: what, why, how, and when. Sloan Management Review, 33(3), 31-39.

11. Brown, B. (1997). How do reputations affect corporate performance? Stock market valuation of reputation for corporate social performance. Corporate Reputation Review, 1(1), 76-80.

12. Cable, D., \& Turban, D. B. (2003). The value of organizational reputation in the recruitment context: a brand-equity perspective. Journal of Applied Social Psychology, 33(11), 2244-2266.

13. Cadwallader, S., Jarvis, C., Bitner, M., \& Ostrom, A. (2010). Frontline employee motivation to participate in service innovation implementation. Journal of the Academy of Marketing Science, 38(2), 219-239.

14. Chongho, L., Myungsook, A., \& Yonghwi, N. (2012). The social dimension of service workers job satisfaction: the perspective of flight attendants. Journal of Service Science and Management, 5, 160-170

15. Chun, R. (2005). Corporate reputation: Meaning and measurement. International Journal of Management Reviews, 7(2), 91-109.

16. Cornelissen, J. P., Haslam, S. A., \& Balmer, J. M. T. (2007). Social identity, organizational identity and corporate identity: Towards an integrated understanding of processes, patternings and products. British Journal of Management, 18(1), 1-16.

17. Cropanzano, R., Byrne, Z. S., Bobocel, D. R., \& Rupp, D. E. (2001). Moral virtues, fairness heuristics, social entities, and other denizens of organizational justice. Journal of Vocational Behavior, 58, 164-209.

18. Dagger, T. S., Danaher, P. J., Sweeney, J. C., \& McColl-Kennedy, J. R. (2013). Selective halo effects arising from improving the interpersonal skills of frontline employees. Journal of Service Research, 16(4), 488-502.

19. Delcourt, C., Gremler, D. D., van Riel, A., \& van Birgelen, M. (2013). Effects of perceived employee emotional competence on customer satisfaction and loyalty: The mediating role of rapport. Journal of Service Management, 24(1), 5-24. 
20. Dutton, J. E., Dukerich, J. M., \& Harquail, C. V. (1994). Organizational images and member identification. Administrative Science Quarterly, 39(2), 239-263.

21. Eccles, J. S., \&Wigfield, A. (2002). Motivational beliefs, values, and goals. Annual Review of Psychology, 53, 109-132.

22. Elfenbein, H. A., Beaupré, M. G., Lévesque, M., \& Hess, U. (2007). Toward a dialect theory: cultural differences in the expression and recognition of posed facial expressions. Emotion, 7, 131-146.

23. Elsbach, K. D., \& Glynn, M. A. (1996). Believing your own "PR": Embedding identification in strategic reputation. Advances in Strategic Management, 13, 65-90.

24. Ettenson, R., \& Knowles, J. (2008). Don't confuse reputation with brand. MIT Sloan Management Review, 49(2), 19-21.

25. Fairfield, K. D., Wagner, R. F., \& Victory, J. (2004). Whose side are you on? Interdependence and its consequences in management of healthcare delivery. Journal of Healthcare Management, 49(1), 17-31.

26. Fisher, C. D., \& Ashkanasy, N. M. (2000). The emerging role of emotions in work life: An introduction. Journal of Organizational Behavior, 21(2), 123-129.

27. Fombrun, C. (1996). Reputation. Boston, MA: John Wiley \& Sons.

28. Fuller, J. B., Hester, K., Barnett, T., Frey, L., Relyea, C., \& Beu, D. (2006). Perceived external prestige and internal respect: new insights into the organizational identification process. Human Relations, 59(6), 815-846.

29. Furman, D. M. (2010). The development of corporate image: a historiographic approach to a marketing concept. Corporate Reputation Review, 13(1), 63-75.

30. Gok, O., Peker, S., \& Hacioglu, G. (2015). The marketing department's reputation in the firm. European Management Journal, 33(5), 366-380.

31. Gotsi, M., \&Wilson, A. M. (2001). Corporate reputation: seeking a definition. Corporate Communications: An International Journal, 6(1), 24-30.

32. Gounaris S., Vassilikopoulou, K., \& Chatzipanagiotou, K. (2010). Internal-market orientation: a misconceived aspect of marketing theory. European Journal of Marketing, 44(11/12), 1667-1699.

33. Gounaris, S. (2008). The notion of internal market orientation and employee job satisfaction: Some preliminary evidence. Journal of Services Marketing, 22, 68-90.

34. Gouthier, M., \& Walter, B. (2006). Professionalization of internal services and encouragement of craftsman's pride. In: D. Streich \& D. Wahl (Eds). Moderne Dienstleistungen - Impulse für Innovation. Frankfurt: Wachstum und Beschäftigung.

35. Gremler, D. D., \& Gwinner, P. K. (2008). Rapport-Building Behaviors Used by Retail Employees. Journal of Retailing, 84(3), 308-324.

36. Grönroos, C. (1984). A Service Quality Model and its Marketing Implications. European Journal of Marketing, 18(4), 36-44.

37. Harris, L. C., \& Ogbonna, E. (2010). Hiding customer complaints: studying the motivations and forms of service employees' complaint concealment behaviors. British Journal of Management, 21(2), 262-279.

38. Helm, S. (2011). Employees' awareness of their impact on corporate reputation. Journal of Business Research, 64, 657-663.

39. Hennig-Thurau, T. (2004). Customer orientation of service employees its impact on customer satisfaction, commitment, and retention. International Journal of Service Industry Management, 15(5), 460-478.

40. Hennig-Thurau, T., \& Thurau, C. (2003). Customer orientation of service employees - toward a conceptual framework of a key relationship marketing construct. Journal of Relationship Marketing, 2(1), 1-32. 
41. Henning-Thurau, T., Groth, M., Paul, M., \& Gremler, D. D. (2006). Are all smiles created equal? How emotional contagion and emotional labor affect service relationships. Journal of Marketing, 70(3), 58-73.

42. Heskett, J., Thomas, L., Jones, O., Loveman, G. W., Sasser, E. W., \& Schlesinger, L. A. (1994). Putting the Service Profit Chain to Work. Harvard Business Review, 2, 164-174.

43. Javadein, S. R. S., Rayej, H., Estiri, M., \& Ghorbani, H. (2011). The role of internal marketing in creation of sustainable competitive advantages. Trends in Applied Scientific Research, 6(4), 364-374.

44. Johnson, O. (1996). Corporate philanthropy: an analysis of corporate contributions. Journal of Business, 39(4), 489-504.

45. Katzenbach, J. R., \& Santamaria, J. A. (1999). Firing up the front line. Harvard Business Review, 77(3), 107-117.

46. Katzenbach, J. (2003). Why pride matters more than money: the power of the world's greatest motivational force. New York, NY: Crown Business.

47. Korschun, D., Bhattacharya, C. B., \& Swain, S. D. (2014). Corporate social responsibility, customer orientation, and the job performance of frontline employees. Journal of Marketing, 78(3), 20-37.

48. Kumar, P., Dass, M., \& Topaloglu, O. (2014). Understanding the drivers of job satisfaction of frontline service employees. Journal of Service Research, 17(4), 367-380.

49. Lindell, M., \& Whitney, D. (2001). Accounting for common method variance in cross-sectional research designs. Journal of Applied Psychology, 86(1), 114-121.

50. Lea, S. E. G., \& Webley, P. (1997). Pride in Economic Psychology. Journal of Economic Psychology, 18(2/3), 323-340.

51. Locke, E. A. (1976). The Nature and Causes of Job Satisfaction. In: M. D. Dunnette (Ed.), Handbook of Industrial and Organizational Psychology (pp. 1297-1343). Boston, MA: Rand McNally College Pub.

52. Löhndof, B., \& Diamantopoulos, A. (2014). Internal branding social identity and social exchange perspectives on turning employees into brand champions. Journal of Service Research, 17(3), 310 325.

53. Madrigal, R. (2001). Social identity effects in a belief-attitude-intentions hierarchy: Implications for corporate sponsorship. Psychology and Marketing, 18(2), 145-165.

54. McKnight, R., \& Hawkrigg, J. (2005). Leading the human side of change. Canadian HR Reporter, 18(21), 17-19.

55. Melton, H. L., \& Hartline, M. D. (2010). Customer and frontline employee influence on new service development performance. Journal of Service Research, 13(4), 411-425.

56. Muriuki, L., Maru, L., \& Kosgei, D. (2016). Internal marketing strategy, employee performance, and organizational commitment in selected public universities in Nairobi County, Kenya. International Journal of Business and Social Science, 6(8), 91-107.

57. Nguyen, H., Groth, M., Walsh, G., \& Henning-Thurau, T. (2014). The impact of service scripts on customer citizenship behavior and the moderating role of employee customer orientation. Psychology \& Marketing, 31(12), 1096-1109.

58. Papasolomou, I. (2006). Can internal marketing be implemented within bureaucratic organisations?. International Journal of Bank Marketing, 24(3), 194-212.

59. Paswan, A., Pelton, L., \& True, S. (2005). Perceived managerial sincerity, feedback-seeking orientation and motivation among frontline employees of a service organization. Journal of Services Marketing, 19, 3-12.

60. Podsakoff, P. M., MacKenzie, S. B., Lee, J-Y., \& Podsakoff, N. P. (2003). Common method biases in behavioral research: a critical review of the literature and recommended remedies. Journal of Applied Psychology, 88(5), 879-903. 
61. Porter, T. W., \& Smith, D. C. (2005). Tactical implementation and Murphy's Law: factors affecting the severity of problems. Journal of Business Research, 58, 1702-1711.

62. Preacher, K. J., \& Hayes, A. F. (2008). Asymptotic and Resampling Strategies for Assessing and Comparing Indirect Effects in Multiple Mediator Models. Behavior Research Methods, 40(3), 879891.

63. Quinn, R. P., \& Magine, T. W. (1973). Evaluation weighted of model of measuring job satisfaction: A Cinderella story. Organizational Behavior and Human Performance, 10(1), 1-23.

64. Riordan, C. M., Gatewood, R. D., \& Bill, J. B. (1997). Corporate image: employee reactions and implications for managing corporate social performance. Journal of Business Ethics, 16(4), 401-412.

65. Salancik, G. R., \& Pfeffer, J. (1977). An examination of need-satisfaction models of job attitudes. Administrative Science Quarterly, 22(3), 427-456.

66. Schaarschmidt, M. (2016). Frontline employees' participation in service innovation implementation: The role of perceived external reputation. European Management Journal, 34(5), 540-549.

67. Seltzer, T., Gardner, E., Bichard, S., \& Callinson, C. (2012). PR in the ER: Managing internal organization public relationships in a hospital emergency department. Public Relations Review, 38, 128136.

68. Shamma, H., \& Hassan, S. (2009). Customer and non-customer perspectives for examining corporate reputation. Journal of Product and Brand Management, 18(5), 326-337.

69. Tajfel, H., \& Turner, J. C. (1979). An integrative theory of intergroup conflict. In: W. G. Austin \& S. Worchel (Eds). The Social Psychology of Intergroup Relations (pp. 7-24). Monterey, CA: Brooks, \& Cole.

70. Tharenou, P., Shaks, A., \& Moore, C. (2007). A review and critique of research on training and organizational-level outcomes. Human Resource Management Review, 17, 251-273.

71. Vlašić, G., \& Langer, J. (2012). Concept of reputation: different perspectives and robust empirical understandings. Market-Tržište, 24(2), 219-244.

72. Walsh, G., \& Beatty, S. E. (2007). Measuring customer-based corporate reputation: scale development, validation, and application. Journal of the Academy of Marketing Science, 35(1), 127-143.

73. Walsh, G., Yang, Z., Dose, D., \& Hille, P. (2015). The effect of job-related demands and resources on service employees' willingness to report complaint Germany versus China. Journal of Service Research, 18(2), 193-209.

74. Yoo, J., \& Arnold, T. J. (2016). Frontline employee customer-oriented attitude in the presence of job demands and resources. Journal of Service Research, 19(1), 102-117. 